\title{
Control of Citrus Canker and Citrus Bacterial Spot with Bacteriophages
}

Botond Balogh, University of Florida, Plant Pathology Department, 1453 Fifield Hall, Gainesville, FL 32611, and The Connecticut Agricultural Experiment Station, 123 Huntington Street, New Haven, CT 06504; B. I. Canteros, Instituto Nacional de Tecnología Agropecuaria Estación Experimental Agropecuaria, Bella Vista, Corrientes, Argentina; and R. E. Stall and J. B. Jones, University of Florida, Plant Pathology Department, 1453 Fifield Hall, Gainesville, FL 32611

\begin{abstract}
Balogh, B., Canteros, B. I., Stall, R. E., and Jones, J. B. 2008. Control of citrus canker and citrus bacterial spot with bacteriophages. Plant Dis. 92:1048-1052.

Bacteriophages, alone or in combination with copper bactericides, were evaluated for managing Asiatic citrus canker and citrus bacterial spot incited by Xanthomonas axonopodis pathovars citri and citrumelo, respectively. In a set of five greenhouse experiments, phage treatment provided consistent control of citrus canker, causing an average of 59\% reduction in disease severity. However, treatment with phage was ineffective if applied with skim milk, a protective formulation, which increases phage residual activity. In nursery settings, phage treatment also reduced disease but was less effective than copper-mancozeb, a chemical bactericide. The integration of phage and copper-mancozeb resulted in equal or less control than copper-mancozeb application alone. Phage treatments were evaluated in a commercial citrus nursery for reducing citrus bacterial spot caused by natural inoculum. Phage treatment provided significant disease reduction on moderately sensitive Valencia oranges in two trials (48 and 35\%); however, on the highly susceptible grapefruit host it was ineffective. In an experimental citrus nursery, phage treatment provided significant control of citrus bacterial spot caused by a phage-sensitive strain, but was equally or less effective than copper-mancozeb. The combination of phage and copper-mancozeb did not increase control compared with copper-mancozeb alone.
\end{abstract}

Additional keywords: biocontrol, biological control

Asiatic citrus canker (ACC), incited by Xanthomonas axonopodis pv. citri (synonym $X$. citrii subsp. citri), is a devastating disease affecting citrus production worldwide $(11,28)$. It affects most commercially grown citrus varieties (11) and causes considerable economic losses by reducing fruit yield and quality, increasing production costs, and triggering market losses due to exclusion policies of canker-free citrus growing regions (12). ACC is exotic to Florida; it was first introduced to the state in 1912, eradicated in 1933, then reintroduced in 1986 and declared eradicated in 1994 (30). The most recent eradication program, initiated in response to a 1995 introduction (11), lasted until January 2006, when it was deemed infeasible to continue. Since that time, ACC has been considered endemic.

Management of ACC relies on an integrated approach which includes: (i) replacement of susceptible citrus species with resistant material; (ii) production of

Corresponding author: Jeffrey B. Jones

E-mail: jbjones@ufl.edu

Accepted for publication 21 February 2008.

doi:10.1094/PDIS-92-7-1048

(C) 2008 The American Phytopathological Society disease-free nursery stock; (iii) reduction of pathogen spread by establishing windbreaks and fences around groves; (iv) preventative copper sprays; and (v) insecticide applications for controlling Asian leafminer (20). However, continuous use of copper compounds leads to soil contamination (18), as well as to the emergence of copper-tolerant phytobacterial strains (22), which in turn results in reduced efficacy of copper bactericides. Widespread appearance of copper-tolerant $X$. axonopodis pv. citri strains and subsequent loss of disease control have already been reported in Argentina $(6,7)$. Mixing maneb or mancozeb fungicides with copper bactericides (copper-mancozeb) increases their bactericidal efficacy $(6,7,22)$; however, full control is unattainable if weather conditions favor disease development.

Clearly, alternative control methods are necessary. Systemic acquired resistance (SAR) inducers, which have been used effectively against a number of bacterial plant diseases $(17,21,23)$, have not been effective in controlling ACC (13). Biological control agents, including antagonistic foliar bacteria, plant growth-promoting bacteria, and bacteriophages, have been successfully used in several pathosystems $(3,5,16)$ and are also promising candidates for control of ACC. Bacteriophages have been used effectively for controlling sev- eral diseases caused by species of Xanthomonas, including bacterial spot of peach, caused by $X$. campestris pv. pruni $(8,27)$, geranium bacterial blight, caused by $X$. campestris pv. pelargonii (9), tomato bacterial spot, caused by $X$. euvesicatoria and $X$. perforans, and xanthomonas leaf blight of onion, caused by $X$. axonopodis pv. allii $(3,10,19,24,25)$.

Recently, a considerable amount of research has been conducted on understanding problems associated with phage treatment of bacterial plant diseases and improving its efficacy. The short residual activity of phage, caused mainly by the detrimental effects of sunlight UV irradiation, was identified as a major hindrance to effective disease control $(3,14)$. Strategies that increased phage longevity, such as the use of formulations that attenuate sunlight damage or evening applications to minimize UV irradiation, resulted in enhanced control (3). Phage treatment also performed well when used as part of an integrated management approach with SAR inducers (25) and antagonistic phyllosphere bacteria (32). Integrating phage with copper compounds, on the other hand, may be more challenging. Ionic copper was found to be toxic to bacteriophages in vitro (2), but in the field, exposure to copper bactericide was several orders of magnitude less detrimental than exposure to sunlight (14). Additionally, copper did not affect phyllosphere phage populations at all if it was applied at least 4 days in advance of phage application. Thus, there is a possibility of successful integration of phage and copper.

Our goal was to evaluate phages as part of an integrated management strategy for controlling ACC. We evaluated skim milk as a protective formulation on phage disease control efficacy and the integration of phage with copper bactericides. We conducted field trials in Argentina, where ACC is endemic, and greenhouse trials in Florida, where regulations prohibited field experiments with ACC at the time of these studies.

We also took advantage of the fact that there is another xanthomonas-incited citrus disease in Florida: citrus bacterial spot (CBS) (29). It is caused by $X$. axonopodis pv. citrumelo, a pathogen with a similar phage sensitivity profile to that of $X$. axonopodis pv. citri (1). Additionally, the 
CBS bacterium is like $X$ axonopodis pv. citri, in that it causes lesions on citrus leaves and stems, infects young tissue, is spread by wind-driven rain, and its severity is greatly increased by Asian leafminer activity (15). Due to these similarities, we deemed that CBS could be used as a reasonable model system for ACC. CBS is endemic to Florida; thus, we were able to conduct field trials for evaluating phage disease control efficacy in this pathosystem.

\section{MATERIALS AND METHODS}

Bacterial strains and bacteriophages.

Bacterial strains used in this study (Table 1) were stored at $-80^{\circ} \mathrm{C}$ in $0.8 \%$ nutrient broth (NB) (BBL, Becton Dickinson and Co., Cockeysville, MD) supplemented with $30 \%$ glycerol. The strains were grown on nutrient agar (NA) medium (Difco) at $28^{\circ} \mathrm{C}$. For preparation of bacterial suspensions, 24-h cultures were suspended in sterile tap water, the concentration adjusted to $5 \times 10^{8} \mathrm{CFU} / \mathrm{ml}$ photometrically, and then diluted appropriately. Bacteria were misted onto the plant foliage with a hand-held sprayer.

Bacteriophages used in this study (Table 2) were stored at $4^{\circ} \mathrm{C}$ in complete darkness and were propagated on their bacterial hosts growing on either semisolid, soft nutrient agar-yeast extract medium (NYA), (0.8\% NB, 0.6\% Bacto Agar [Difco], and $0.2 \%$ Yeast Extract [Difco]), or in liquid culture in NB medium. Sterilized tap water or SM buffer (0.05 M Tris- $\mathrm{HCl}(\mathrm{pH} 7.5)$, $0.1 \mathrm{M} \mathrm{NaCl}, 10 \mathrm{mM} \mathrm{MgSO}_{4}$, and $1 \%$ gelatin) was used for preparing phage suspensions. Phage concentrations were determined by serial dilutions and subsequent plaque assay on NYA plates without bottom agar, as previously described (26).

Disease assessment and data analysis. Disease progress was evaluated by one of three methods depending on the location and level of disease. In Florida, (i) disease incidence or (ii) disease severity was assessed, depending on the disease pressure; whereas in Argentina, (iii) disease intensity was evaluated.

Disease incidence was calculated as the percentage of diseased plants. Disease

Table 1. Bacterial strains used in this study

\begin{tabular}{|c|c|c|}
\hline Strain & Origin & Source \\
\hline \multicolumn{3}{|c|}{ Xanthomonas axonopodis pv. citri } \\
\hline XI2000-00120 & Florida & X. Sun ${ }^{y}$ \\
\hline Xc05-2592 & Argentina & B. I. Canteros ${ }^{z}$ \\
\hline \multicolumn{3}{|c|}{$X$. axonopodis pv. citrumelo } \\
\hline Xacm 36 & Florida & This study \\
\hline Xacm 47 & Florida & This study \\
\hline S4m & Florida & This study \\
\hline
\end{tabular}

y Florida Department of Agriculture and Consumer Services, Division of Plant Industry, Gainesville.

${ }^{\mathrm{z}}$ Instituto Nacional de Tecnología Agropecuaria Estación Experimental Agropecuaria, Bella Vista, Corrientes, Argentina. severity was estimated using the HorsfallBarratt (HB) scale (4). The HB values were then converted to estimated mean percentages using the Elanco conversion tables for Barratt-Horsfall rating numbers (ELANCO Products Co., Indianapolis, IN). If disease was assessed more than twice, the area under the disease progress curve (AUDPC) was computed by trapezoidal integration of the disease percentage values taken at different timepoints, as described (31). Disease intensity was determined by collecting all diseased leaves from a plot $(3,500$ to 5,000 leaves), counting the total number of lesions, and calculating the average lesion number per diseased leaf (i.e., Disease intensity = lesion number/number of diseased leaves).

Analysis of variance and subsequent separation of sample means by the WallerDuncan $k$-ratio $t$ test or by least square means method was carried out using SAS System for Windows program release 8.02 (SAS Institute, Cary, NC).

Greenhouse trials. Duncan grapefruit plants, which are highly susceptible to ACC, were grown in $15-\mathrm{cm}$ plastic pots in Terra-Lite agricultural mix (Scott Sierra Horticultural Products Co., Marysville, $\mathrm{OH})$ in the citrus canker quarantine glasshouse of the Division of Plant Industry in Gainesville, FL, at 25 to $30^{\circ} \mathrm{C}$. The plants were heavily pruned and fertilized to induce a new flush of growth that was very susceptible to new infections. Approximately 3 weeks later, the emerging foliage was treated with a mixture of equal amounts of phages CP2, ФXac2005-1, $\operatorname{cc} \Phi 7$, and $\operatorname{cc} \Phi 13$ (test 1: $5 \times 10^{9}$ plaque forming units $(\mathrm{PFU}) / \mathrm{ml}$; test 2: $1 \times 10^{9}$ PFU/ml; tests 3 to $5: 1 \times 10^{8} \mathrm{PFU} / \mathrm{ml}$ of each phage) in the evening, and the plants were covered with white plastic bags. Phages were applied either in sterilized tap water or in a suspension of $0.75 \%$ skim milk powder. The following morning, plants were removed from the bags, allowed to dry, inoculated with $X$. axonopodis pv. citri strain XI2000-00120 (test 1: 1 $\times 10^{8} \mathrm{CFU} / \mathrm{ml}$; tests 2 to $5: 5 \times 10^{6}$ $\mathrm{CFU} / \mathrm{ml}$ ), and covered with the bags for an additional $24 \mathrm{~h}$ before placing on the greenhouse bench. Four plants were used per treatment. Disease severity was assessed 3 to 4 weeks after inoculation as described above.

Table 2. Bacteriophages used in the study

\begin{tabular}{llll}
\hline Phage & Bacterial host & Origin & Source \\
\hline CP2 & XI2000-00120 & Japan & J. S. Hartung \\
ФXac2005-1 & XI2000-00120 & Unknown & Unknown \\
ccФ7 & XI2000-00120 & United States & L. E. Jackson \\
ccФ13 & XI2000-00120 & United States & L. E. Jackson \\
ФXacm2004-4 & Xacm 36 & Florida & This study \\
ФXacm2004-16 & Xacm 36 & Florida & This study \\
ФX44 & Xacm 47 & United States & L. E. Jackson \\
ФXaacA1 & XI2000-00120 & Argentina & This study \\
\hline
\end{tabular}

${ }^{y}$ U.S. Department of Agriculture, Agricultural Research Service, Fruit Laboratory, Beltsville, MD.

z OmniLytics Inc., Salt Lake City, UT.
ACC nursery trials. In order to investigate whether bacteriophages are capable of reducing citrus canker disease progress under field conditions and if they can be feasibly integrated with copper-based chemical bactericides, grapefruit plants were inoculated with a phage-sensitive $X$. axonopodis pv. citri strain and then (i) were left untreated or were treated (ii) twice weekly with a bacteriophage mixture, (iii) weekly with copper-mancozeb, or (iv) with both phage (twice weekly) and copper-mancozeb (once weekly). Two trials were conducted within an experimental citrus nursery in Bella Vista, Corrientes, Argentina from January to April 2006. The trials were set up in a split-plot design with two main treatments, phage and no phage, and two subtreatments, copper-mancozeb and no copper-mancozeb. The subtreatments were randomly replicated four times within the main treatments. The experimental units were 5- or 2.5-m-long runs of grapefruit spaced 40 $\mathrm{cm}$ apart in trials 1 and 2, respectively. The plants were inoculated with a local $X$. axonopodis pv. citri strain, $\mathrm{Xc05}-2592$, in January and then reinoculated in February. A locally isolated bacteriophage (ФXaacA1, 106 PFU/ml, applied with $0.75 \%$ skim milk powder) was sprayapplied twice weekly throughout the trials using a hand pressurized backpack sprayer. For copper-mancozeb treatment, a mixture of $3 \mathrm{~g}$ /liter Caurifix WG (a.i., 84\% copperoxychloride; BASF Co.) plus 2 g/liter Dithane M80 (a.i., 80\% mancozeb; Dow AgroSciences LLC, Indianapolis, IN) was spray-applied weekly. Treatments were applied for 12 weeks, and disease incidence was assessed at the end of April.

CBS trials in a commercial nursery. To evaluate the efficacy of bacteriophages under field conditions in Florida, a threephage mixture was applied twice weekly throughout the growing season in a commercial citrus nursery in Avon Park, FL, for controlling CBS caused by naturally occurring populations of $X$. axonopodis pv. citrumelo. The trials were conducted from 9 August to 11 November 2004. Two trials were established in sections of Valencia orange, which is moderately susceptible to CBS, whereas the third one was in a grapefruit section, which is highly susceptible to CBS. 
The trial sites consisted of a double-row of plants spaced $10 \mathrm{~cm}$ apart, which was divided into six 6-m-long plots separated by $3-\mathrm{m}$ buffer zones. Three plots received phage-treatment while three were left untreated. A mixture of three bacteriophages (ФXacm2004-4, ФXacm2004-16 [both isolated from the same nursery], and $\Phi X 44,2.4 \times 10^{8} \mathrm{PFU} / \mathrm{ml}$ each), blended in a suspension of $0.75 \%$ skim milk powder, was applied at dawn using a hand pressurized backpack sprayer. CBS disease severity was evaluated five times during the experiment using the Horsfall-Barratt scale. The nursery was later destroyed due to appearance of ACC, thus prohibiting further trials.

CBS trial in an experimental nursery. In order to investigate whether phage and copper-mancozeb treatments can be integrated in management of CBS, two experiments were carried out in an experimental nursery. Swingle citrumelo plants, which are highly susceptible to $X$. axonopodis pv. citrumelo, were inoculated with a phage-sensitive strain and then were either (i) left untreated or were treated (ii) twice weekly with a phage mixture, (iii) weekly with copper-mancozeb, or (iv) were subjected to both phage (twice weekly) and copper-mancozeb (once weekly) treatments. The experiments were carried out during summer and fall of 2006 at the experimental citrus nursery of the Plant Science Unit of the University of Florida in Citra, FL. The experiments were set up in split-plot designs as described above for the ACC nursery trial. The experimental unit consisted of nine Swingle citrumelo plants spaced $25 \mathrm{~cm}$ apart. The plants were inoculated with $X$. axonopodis pv. citrumelo strain $\mathrm{S} 4 \mathrm{~m}\left(10^{7} \mathrm{CFU} / \mathrm{ml}\right.$ suspension, amended with $0.025 \%$ Silwet L-77 [Loveland Industries, Greeley, $\mathrm{CO}]$ ). The phage treatment, which consisted of three phages $\left(\operatorname{cc} \Phi 13, \alpha\right.$-MME, and $\Phi 5536,1 \times 10^{8}$ $\mathrm{PFU} / \mathrm{ml}$ each, applied with $0.75 \%$ skim milk formulation) was applied twice weekly, Mondays and Thursdays, in the evenings using a hand pressurized backpack sprayer. The copper-mancozeb treatment (2.5 g/liter Manzate 75DF [a.i. 75\% mancozeb; E. I. du Pont de Nemours \& Co.] and 3.6 g/liter Kocide 2000 [a.i. $53.8 \%$ copper hydroxide; du Pont]) was applied once per week, on Saturdays, 2 days apart from both phage applications in order to minimize the harm to phages. In the first experiment, disease pressure was low; thus, disease incidence was determined on 16 September. In the second trial, however, disease was more prevalent and so disease severity was assessed four times (23 and 29 September, 6 and 15 October).

\section{RESULTS}

Effect of bacteriophage treatment and use of protective skim milk formulation on citrus canker disease development in the greenhouse. In four of the five tests, there were significant differences among

Table 3. Effect of bacteriophage treatment and use of skim milk formulation on Asiatic citrus canker disease development incited by a phage-sensitive Xanthomonas axonopodis pv. citri strain on Duncan grapefruit in the greenhouse

\begin{tabular}{lcclc}
\hline & \multicolumn{3}{c}{ Mean disease severity $^{\mathbf{x}}$} & \\
\cline { 2 - 4 } Treatment $^{\mathbf{y}}$ & Phage & Formulated phage & UTC & $\boldsymbol{P}$ \\
\hline Test 1 & $52.6 \mathrm{~b}^{\mathrm{z}}$ & $75.1 \mathrm{a}$ & $72.1 \mathrm{a}$ & 0.012 \\
Test 2 & 5.9 & 11.7 & 16.0 & 0.197 \\
Test 3 & $12.5 \mathrm{~b}$ & $23.4 \mathrm{a}$ & $24.2 \mathrm{a}$ & 0.021 \\
Test 4 & $16.4 \mathrm{~b}$ & $\mathrm{Nt}$ & $55.2 \mathrm{a}$ & 0.045 \\
Test 5 & $5.2 \mathrm{~b}$ & $\mathrm{Nt}$ & $41.7 \mathrm{a}$ & 0.026 \\
\hline
\end{tabular}

${ }^{x}$ Disease severity: percentage of diseased plant surface area.

y Phage: a four-phage mixture applied in sterile tap water (test $1: 2 \times 10^{10}$ plaque forming units (PFU)/ml; test 2: $4 \times 10^{9} \mathrm{PFU} / \mathrm{ml}$; tests 3 to $5: 4 \times 10^{8} \mathrm{PFU} / \mathrm{ml}$ ) applied in sterile tap water. Formulated phage: same phage mixture applied in a suspension of $0.75 \%$ skim milk powder. UTC: untreated control.

${ }^{\mathrm{z}}$ Means within the same row followed by the same letter are not significantly different according to the Waller-Duncan $k$-ratio $t$ test at $P=0.05$. Nt $=$ not tested.

Table 4. Effect of phage and copper-mancozeb treatments on citrus canker disease development incited by a phage-sensitive Xanthomonas axonopodis pv. citri strain in a citrus nursery in Argentina

\begin{tabular}{lccccc}
\hline & & \multicolumn{3}{c}{ Mean disease intensity } & \\
\cline { 3 - 5 } Treatment & UTC $^{\mathbf{x}}$ & Phage & CM & Phage+CM & $\boldsymbol{P}$ \\
\hline Trial 1 & $2.6 \mathrm{a}^{\mathrm{z}}$ & $2.0 \mathrm{~b}$ & $1.6 \mathrm{c}$ & $1.8 \mathrm{bc}$ & $<0.001$ \\
Trial 2 & $3.1 \mathrm{a}$ & $2.1 \mathrm{~b}$ & $1.6 \mathrm{c}$ & $2.0 \mathrm{~b}$ & $<0.001$ \\
\hline
\end{tabular}

${ }^{x}$ Disease intensity $=$ lesion number per diseased leaf.

y UTC: untreated control. Phage: a suspension of bacteriophage ФXaacA1 $\left(10^{6} \mathrm{PFU} / \mathrm{ml}\right)$, amended with $0.75 \%$ skim milk powder, was spray-applied twice weekly. CM (copper-mancozeb): mixture of Caurifix WG (a.i. $84 \%$ copper-oxychloride) and Dithane M80 (a.i. $80 \%$ mancozeb) was spray-applied weekly at commercial rates ( $3 \mathrm{~g} /$ liter and $2 \mathrm{~g} /$ liter, respectively).

${ }^{\mathrm{z}}$ Means within the same row followed by the same letter are not significantly different based on least square means differences at $P=0.05$. treatments (Table 3). In these tests, phage treatment, if applied without skim milk, significantly reduced disease severity. If applied with skim milk, however, phages did not cause any disease reduction. This happened despite the fact that skim milk contributed to better phage persistence: phage populations ranged from $10^{4}$ to $10^{7}$ $\mathrm{PFU} / \mathrm{g}$ leaf tissue 2 days after application if applied with skim milk, but were not detected if applied without skim milk (data not shown).

Effect of phage and copper-mancozeb treatments on citrus canker disease development in a citrus nursery. Phage application significantly reduced citrus canker disease severity, but was less effective than copper-mancozeb in both trials (Table 4). The combination of phage and copper-mancozeb treatments did not result in increased control over copper-mancozeb alone. To the contrary, plants treated with both phage and copper-mancozeb were as severely diseased as the plants treated with phage only, and in one of two trials were significantly more diseased than the copper-mancozeb-treated plants.

Effect of bacteriophage treatment on citrus bacterial spot disease development in a commercial citrus nursery. Phage treatment significantly reduced disease progress on the moderately susceptible Valencia oranges in both trials $(P=$ 0.002 and $P=0.036$ ) (Table 5). However, on highly susceptible grapefruits, the phage treatment did not result in significant disease suppression $(P=0.159)$.

Effect of bacteriophage and coppermancozeb treatments on CBS in an experimental nursery. In the first experiment, under low disease pressure, phage, copper-mancozeb, and their combined application all reduced disease incidence significantly and provided similar levels of control (Table 6). In the second experiment, under higher disease pressure, all three treatments significantly reduced disease severity compared to the untreated control, but provided different levels of control. Phage-treated plants had significantly more disease than the coppermancozeb treated ones. Plants that received both phage and copper-mancozeb had equal levels of disease to the plants receiving copper-mancozeb alone.

\section{DISCUSSION}

One of the greatest challenges in using bacteriophages for plant disease control is their extremely short residual activity in the phyllosphere. Several studies indicated that phage populations can drop to undetected levels hours after applications $(1,14)$. Additionally, it has been shown that phage needs to be applied at high concentrations for effective disease control (1). Moreover, a previous study demonstrated that phage only provides sufficient control if present on the plant foliage prior to the arrival of bacterial inoculum, and it is inef- 
fective in reducing bacterial populations after ingress (8). Taken together, it is likely that phages only provide an adequate level of protection for a few hours after application. To enhance the effectiveness of phage-based disease control, phage persistence needs to be increased. In earlier work, we demonstrated that milk-, flour-, and sugar-based formulations were effecthis increased longevity translated into improved disease control in the tomato bacterial spot pathosystem (2). It was noted, however, that these formulations, if applied without phage, actually increased (1). Nevertheless, the benefit outweighed the harm and there was a net gain in disease control efficacy.

In this study, we determined that application of phages with skim milk compromised disease control in the greenhouse, even though it did contribute to increased phage longevity. It seems likely that under these conditions, skim milk contributed more to the progress of the disease than to the enhancement of disease control. However, the possibility cannot be excluded that skim milk somehow interfered with the biocontrol activity of these phages by some other means. The mode of action by which skim milk may increase disease severity is unclear. It acts as a wetting agent, and by breaking down surface tension, it probably helps pathogen ingress. Additionally, it may serve as a carbon and nitrogen source for the bacterium, thus aiding in survival. Altogether, increasing tive in increasing phage longevity, and that disease severity of tomato bacterial spot

phage longevity is critical for efficient and reliable disease control; however, the currently available formulations interfere with disease control to a certain extent and cannot be used in every pathosystem. There is clearly a need for developing alternative formulations that increase phage residual activity without compromising disease control.

Bacteriophage is an organic bactericide, and combining it with control measures of different modes of action may result in substantial increase in disease control. Phage was successfully integrated with SAR inducers in management of tomato bacterial spot and xanthomonas leaf blight of onion $(19,24,25)$. Combined application of bacteriophages with bacterial biocontrol agents, which served both as propagating hosts for the phage and as antagonists of the target bacterium, was a successful strategy in controlling fire blight of pear and tobacco bacterial wilt $(32,33)$. There is also a need for integrating the use of phages and copper-based bactericides, mainly because copper is often the only available effective control measure for a number of bacterial diseases. However, our results showed no benefit in combining these two treatments. To the contrary, in the ACC nursery trials, the addition of phage may have had a negative effect on copper efficacy (Table 4). While it is not clear what caused this phenomenon, it is possible that the high amount of milk protein deposited on the plant foliage with the frequent skim-milk-formulated phage applications tied up free copper ions, thereby

Table 5. Effect of bacteriophage treatment on citrus bacterial spot disease development incited by naturally occurring Xanthomonas axonopodis pv. citrumelo strains in a commercial citrus nursery

\begin{tabular}{llcc}
\hline & \multicolumn{2}{c}{ Mean AUDPC $^{\mathbf{w}}$} & \\
\cline { 2 - 3 } Treatment $^{\mathbf{x}}$ & Phage & UTC & $\boldsymbol{P}$ \\
\hline Trial 1 & $173^{\mathrm{z}}$ & 331 & 0.002 \\
Trial 2 & 169 & 261 & 0.036 \\
Trial 3 & 128 & 154 & 0.159 \\
\hline
\end{tabular}

w AUDPC: area under the disease progress curve.

$x$ Phage: a three-phage mixture $\left(7 \times 10^{8}\right.$ plaque forming units $\left./ \mathrm{ml}\right)$, amended with $0.75 \%$ skim milk powder, was applied twice weekly. UTC: untreated control.

y Trials 1 and 2 were conducted with Valencia orange, trial 3 with Ruby Red grapefruit.

${ }^{\mathrm{z}}$ Means compared by $t$ test.

Table 6. Effect of bacteriophage and copper-mancozeb treatments on citrus bacterial spot disease development incited by a phage sensitive Xanthomonas axonopodis pv. citrumelo in an experimental citrus nursery

\begin{tabular}{|c|c|c|c|c|c|}
\hline & \multicolumn{4}{|c|}{ Treatment $^{\mathrm{w}}$} & \multirow[b]{2}{*}{$P$} \\
\hline & UTC & Phage & $\mathbf{C M}$ & Phage $+\mathrm{CM}$ & \\
\hline $\begin{array}{l}\text { Test 1: mean disease } \\
\text { incidence }^{\mathrm{x}}(\%)\end{array}$ & $22.2 \mathrm{a}^{\mathrm{y}}$ & $8.9 \mathrm{~b}$ & $3.3 \mathrm{~b}$ & $5.6 \mathrm{~b}$ & 0.012 \\
\hline Test 2: mean AUDPC & $24.3 \mathrm{a}$ & $14.9 \mathrm{~b}$ & $4.0 \mathrm{c}$ & $2.0 \mathrm{c}$ & $<0.001$ \\
\hline
\end{tabular}

${ }^{\mathrm{w}}$ UTC: untreated control. Phage: a three-phage mixture $\left(3 \times 10^{8}\right.$ plaque forming units $\left./ \mathrm{ml}\right)$, amended with $0.75 \%$ skim milk powder, was applied twice weekly. CM (copper-mancozeb): mixture of Kocide 2000 (a.i. 53.8\% copper hydroxide) and Manzate 75DF (a.i. 75\% mancozeb) was spray-applied weekly at commercial rates ( $3.6 \mathrm{~g} /$ liter and $2.5 \mathrm{~g} /$ liter, respectively).

${ }^{\mathrm{x}}$ Disease incidence: percentage of plants exhibiting CBS symptoms.

${ }^{y}$ Means within the same row followed by the same letter are not significantly different based on least square means differences at $P=0.05$.

${ }^{\mathrm{z}}$ AUDPC: area under the disease progress curve. reducing copper efficacy. Conversely, copper probably negatively impacted phage survival due to the tight spray schedule in these trials (two phage sprays and one copper spray per week): copper-mancozeb and phage sprays were applied only 2 days apart instead of the recommended 4 days (14). However, this negative interaction should not be an issue in a real citrus grove situation, where copper sprays are applied only four to six times during the growing season (6).

In our trials, phage treatment provided a moderate level of control of CBS in a commercial setting, where diverse populations of the pathogen exist. We observed better control of CBS when, instead of relying on natural inoculation of diverse strains, plants were inoculated with a single $X$. axonopodis pv. citrumelo strain with the chance for introduction of external populations being minimized due to spatial separation of the experimental location. However, just as in the case of ACC trials, phages provided a lower level of disease suppression than copper-mancozeb. Furthermore, despite the careful timing for maximizing the interval between phage and copper-mancozeb applications, no synergistic effect resulted from the combined applications.

In summary, phage treatment is a promising novel approach for ACC and CBS management. It requires further evaluation as to whether the level of control achieved with phages would be economically feasible and satisfactory in commercial citrus nurseries for managing CBS or for producing ACC-free nursery stock. Additionally, it remains to be seen whether phage application can be scaled up to commercial grove settings. The twice-weekly spray schedule used in this study might be too frequent for a practical, economically feasible spray program, so the relation of application frequency and control efficacy should be further investigated before considering commercialization. Likewise, alternative formulations that enhance activity of phage without enhancing bacterial ingress need to be developed.

\section{ACKNOWLEDGMENTS}

This research was supported by the USDA special grant (J. B. Jones, R. E. Stall, and X. Sun, USDA 2001-34446-10781-S).

\section{LITERATURE CITED}

1. Balogh, B. 2002. Strategies of improving the efficacy of bacteriophages for controlling bacterial spot of tomato. M.S. thesis. University of Florida, Gainesville.

2. Balogh, B., Jones, J. B., Momol, M. T., and Olson, S. M. 2005. Persistence of bacteriophages as biocontrol agents in the tomato canopy. Pages 299-302 in: Proc. 1st IS on tomato diseases; June 21-24, 2004; Orlando, FL. M. T. Momol, P. Ji, and J. B. Jones, eds. Acta Hortic. (ISHS) 695.

3. Balogh, B., Jones, J. B., Momol, M. T., Olson, S. M., Obradovic, A., King, P., and Jackson, L. E. 2003. Improved efficacy of newly formulated bacteriophages for management of bacte- 
rial spot on tomato. Plant Dis. 87:949-954.

4. Barratt, R. W., and Horsfall, J. G. 1945. An improved grading system for measuring plant disease. Phytopathology 35:655.

5. Byrne, J. M., Dianese, A. C., Ji, P., Campbell, H. L., Cuppels, D. A., Louws, F. J., Miller, S. A., Jones, J. B., and Wilson, M. 2005. Biological control of bacterial spot of tomato under field conditions at several locations in North America. Biol. Control 32:408-418.

6. Canteros, B. I. 2002. Control of citrus canker caused by strains of Xanthomonas axonopodis pv. citri susceptible and resistant to copper. (Abstr.) Phytopathology 92:S116.

7. Canteros, B. I. 2004. Management of citrus canker in Argentina. A review. Proc. Int. Soc. Citric. 2:696-704.

8. Civerolo, E. L., and Keil, H. L. 1969. Inhibition of bacterial spot of peach foliage by Xanthomonas pruni bacteriophage. Phytopathology 59:1966-1967.

9. Flaherty, J. E., Harbaugh, B. K., Jones, J. B., Somodi, G. C., and Jackson, L. E. 2001. Hmutant bacteriophages as a potential biocontrol of bacterial blight of geranium. HortScience 36:98-100.

10. Flaherty, J. E., Jones, J. B., Harbaugh, B. K., Somodi, G. C., and Jackson, L. E. 2000. Control of bacterial spot on tomato in the greenhouse and field with H-mutant bacteriophages. HortScience 35:882-884

11. Gottwald, T. R., Graham, J. H., and Schubert, T. S. 2002. Citrus canker: The pathogen and its impact. Plant Health Progress. http://www. plantmanagementnetwork.org/pub/php/review/ citruscanker/

12. Gottwald, T R, Hughes, G., Graham, J. H Sun, X., and Riley, T. 2001. The citrus canker epidemic in Florida: The scientific basis of regulatory eradication policy for an invasive species. Phytopathology 91:30-34.

13. Graham, J. H., and Leite, R. P., Jr. 2004. Lack of control of citrus canker by induced systemic resistance compounds. Plant Dis. 88:745-750.

14. Iriarte, F. B., Balogh, B., Momol, M. T., Smith, L. M., Wilson, M., and Jones, J. B. 2007. Factors affecting survival of bacteriophage on tomato leaf surfaces. Appl. Environ. Microbiol. 73:1704-1711.
15. Jesus, W. C., Jr., Belasque, J., Jr., Amorim, L., Christiano, R. S. C., Parra, J. R. P., and Bergamin Filho, A. 2006. Injuries caused by citrus leafminer (Phyllocnistis citrella) exacerbate citrus canker (Xanthomonas axonopodis pv. citri) infection. Fitopatol. Bras. 31:277-283.

16. Ji, P., Campbell, H. L., Kloepper, J. W., Jones, J. B., Suslow, T. V., and Wilson, M. 2006. Integrated biological control of bacterial speck and spot of tomato under field conditions using foliar biological control agents and plant growth-promoting rhizobacteria. Biol. Control 36:358-367.

17. Ji, P., Momol, M. T., Pradhanang, P. M., Olson, S. M., Mayfield, J. L., and Jones, J. B. 2004. Acibenzolar-S-methyl enhanced host resistance in tomato against Ralstonia solanacearum. (Abstr.) Phytopathology 94:S46.

18. Koller, W. 1998. Chemical approaches to managing plant pathogens. Pages 337-376 in: Handbook of Integrated Pest Management. J. R. Ruberson, ed. Marcel Dekker Inc., New York.

19. Lang, J. M., Gent, D. H., and Schwartz, H. F. 2007. Management of xanthomonas leaf blight of onion with bacteriophages and a plant activator. Plant Dis. 91:871-878.

20. Leite, R. P., Jr., and Mohan, S. K. 1990. Integrated management of the citrus bacterial canker disease caused by Xanthomonas campestris pv. citri in the State of Paraná, Brazil. Crop Prot. 9:3-7.

21. Louws, F. J., Wilson, M., Campbell, H. L., Cuppels, D. A., Jones, J. B., Shoemaker, P. B., Sahin, F., and Miller, S. A. 2001. Field control of bacterial spot and bacterial speck of tomato using a plant activator. Plant Dis. 85:481-488.

22. Marco, G. M., and Stall, R. E. 1983. Control of bacterial spot of pepper initiated by strains of Xanthomonas campestris pv. vesicatoria that differ in sensitivity to copper. Plant Dis. 67:779-781.

23. Maxson-Stein, K., He, S. Y., Hammerschmidt, R., and Jones, A. L. 2002. Effect of treating apple trees with acibenzolar- $S$-methyl on fire blight and expression of pathogenesis-related protein genes. Plant Dis. 86:785-790.

24. Obradovic, A., Jones, J. B., Momol, M. T.,
Balogh, B., and Olson, S. M. 2004. Management of tomato bacterial spot in the field by foliar applications of bacteriophages and SAR inducers. Plant Dis. 88:736-740.

25. Obradovic, A., Jones, J. B., Momol, M. T., Olson, S. M., Jackson, L. E., Balogh, B., Guven, K., and Iriarte, F. B. 2005. Integration of biological control agents and systemic acquired resistance inducers against bacterial spot on tomato. Plant Dis. 89:712-716.

26. Rizvi, S., and Mora, P. T. 1963. Bacteriophage plaque-count assay and confluent lysis on plates without bottom agar layer. Nature 200:1324-1325

27. Saccardi, A., Gambin, E., Zaccardelli, M., Barone, G., and Mazzucchi, U. 1993. Xanthomonas campestris pv. pruni control trials with phage treatments on peaches in the orchard. Phytopathol. Mediterr. 32:206-210.

28. Schaad, N. W., Postnikova, E., Lacy, G. Sechler, A. J., Agarkova, I., Stromberg, P., and Vidaver, A. 2005. Emended classification of xanthomonad pathogens on citrus. Syst. Appl. Microbiol. 29:690-695.

29. Schoulties, C. L., Civerolo, E. L., Miller, J. W., Stall, R. E., Krass, C. J., Poe, S. R., and Ducharme, E. P. 1987. Citrus canker in Florida. Plant Dis. 71:388-395.

30. Schubert, T. S., Rizvi, S. A., Sun, $X$ Gottwald, T. R., Graham, J. H., and Dixon, W. N. 2001. Meeting the challenge of eradicating citrus canker in Florida - Again. Plant Dis. 85:340-356.

31. Shaner, G., and Finnley, R. E. 1977. The effect of nitrogen fertilization on the expression of slow-mildewing resistance in Knox wheat Phytopathology 67:1051-1056.

32. Svircev, A. M., Lehman, S. M., Kim, W.-S. Barszcz, E., Schneider, K. E., and Castle, A. J. 2006. Control of the fire blight pathogen with bacteriophages. Pages 259-261 in: Proc. 1st Int. Sympos. Biol. Control Bacterial Plant Dis. W. Zeller and C. Ullrich, eds. Seeheim/ Darmstadt, Germany.

33. Tanaka, H., Negishi, H., and Maeda, H. 1990. Control of tobacco bacterial wilt by an avirulent strain of Pseudomonas solanacearum M4S and its bacteriophage. Ann. Phytopathol. Soc. Jpn. 56:243-246. 